International Journal of Environmental, Sustainability, and Social Sciences

ISSN 2720-9644 (print); ISSN 2721-0871 (online)

https://journalkeberlanjutan.com/index.php/ijesss

Volume: 2

Number: 3

Page: 244-249

\section{Article History:}

Received: 2021-07-25

Revised: 2021-08-17

Accepted: 2021-11-18

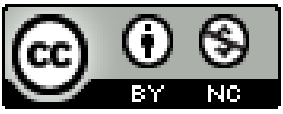

\title{
COOPERATIVE WORK A FUNDAMENTAL STRATEGY IN PRIMARY EDUCATION
}

${ }^{1}$ Amparo Rosa Montellanos SOLÍS, ${ }^{2}$ Johnny Félix Farfán PIMENTEL, 3 Janet Meluzka García RIVEROS, ${ }^{4}$ Luis Carmelo Fuertes MEZA

1,2,3,4Universidad César Vallejo, Perú

Corresponding author: Johnny Félix Farfán PIMENTEL

Universidad César Vallejo, Perú

Email: ereynosa@ucv.edu.pe

\section{Abstract:}

This article provides analysis and review of the bibliographic about cooperative work as a fundamental strategy for acquiring competencies, strengthening interpersonal relationships, construction knowledge, attitudes, and management of skills such as communication, autonomy, leadership, decision-making, and primary school motivation. Learning depends not only on the individual but effort of the group to achieve the expected purpose. Since a strategy that seeks methodological, active, participatory, dynamic change, awakens the interest of students to discover, learn, innovate, internalize, consolidate learning cooperatively working in small groups to expand their learning, seeking the benefit of all in which they assume the role of protagonists of their own learning developing in different contexts, work in a climate of satisfaction, understanding, respect, and tolerance. In the first instance, the different conceptions about cooperative work by recognized authors are known. Second, information is provided on the characteristics, importance of cooperative work, structure used by the teacher to carry activities.

Keywords: Cooperative Work; Positive Interdependence; Interpersonal Skills Cite this as: SOLIS, A.R.M, PIMENTEL, J.F., RIVEROS, J.M.G, MEZA, L.C.F, (2021) Cooperative Work A Fundamental Strategy In Primary Education, International Journal of Environmental, Sustainability, and Social Sciences, 2 (3), 244-249

\section{INTRODUCTION}

In the current educational context, the training of students is based on an approach by competencies to achieve the integral development of students, reflecting learning based on real situations, responding to the solution of current problems; for this, the curriculum states that students face challenges, challenges, think, observe, reflect, search, analyze reliable information, conduct dialogues, interact with your peers instead of working individually. Cooperative work consists of working together to achieve common objectives, achieving individual and group benefits; working in small groups maximizes their own learning (Johnson et al., 1999; Holubec 1994). Likewise, cooperative work is an active educational methodology based on interaction in workgroups with a minimum number of students; each one internalizes co-responsibility in their learning according to the theme to be developed (Bermejo et al., 2020). Cooperative work is an active strategy in which students work in groups to enhance their learning. It is characterized by collaboration, participation, mutual help. This methodological approach focuses on encouraging dialogue, analysis, and shared reflection among its members, with the participation of a mediator (Gutiérrez-Fresneda et al., 2020). Likewise, this strategy allows negotiation between all the members to agree on the task and obtain a common result by assuming responsibilities equally (Izquierdo et al., 2019). In addition, it favors educational interaction in the classroom; students develop learning by mobilizing all their capacities, abilities, skills, and affectivity, managing to train competent students (Molina, 2020); allowing students to help each other, share ideas, experiences and develop their social skills (Arias 2017). Likewise, the use of the cooperative learning technique allows modifying the individualistic and competitive disposition of the student, increasing their motivation, autonomy, and responsibility through active and constructive communication (Fraile, 2008, cited by Garrote et al., 2019). Therefore, collaboration is key to 


\section{International Journal of Environmental, Sustainability, and Social Sciences ISSN 2720-9644 (print); ISSN 2721-0871 (online) \\ https://journalkeberlanjutan.com/index.php/ijesss}

developing students' talent, since a series of competencies are developed, becoming a source of stimulation and creativity, being essential for mutual support, it is a process of respect for skills and knowledge of others, promoting inclusion (Vázquez et al., 2017).

In the present study, a literature review of different scientific and academic journals has been carried out to systematize cooperative work's epistemological and praxiological theoretical bases as a fundamental strategy in primary education. The methods used were analysis-synthesis, inductive-deductive. As a purpose, it was proposed to collect, analyze and systematize information relevant to cooperative work as a fundamental strategy in Primary Education. For the epistemological and praxiological foundation of cooperative learning, and analysis, synthesis of different articles related to cooperative work, an active methodology for the achievement of learning, didactic and pedagogical strategy, training tool, findings, experiences in students, sought in the databases such as Scopus, EBSCO, ProQuest, Scielo, AcademicOneFile. In the educational environment, the interaction work between students stands out, in this context, it is possible to distinguish some characteristics that facilitate the teaching-learning process, among which we can mention those proposed by (Díaz \& Hernández 1999 cited by Bustamante 2017) and other authors: positive interdependence, face-to-face interaction, individual responsibility, interpersonal skills, and group processing or self-assessment. Positive interdependence consists of creating a bond between colleagues, clearly mentioning the task and the group objective that they have to carry out with the intention that everyone knows how to achieve the expected purpose together. Therefore, each member of the group must be clear that the effort of each one depends on the success of the others. (Johnson et al., 1999). To enhance this characteristic, students have to be trained with a collective proposal. There are structures such as collective rewards, division of labor, dependence on resources, among others. (Estrada et al., 2016).

Face-to-face interaction is achieved when there is mutual interaction and a verbal exchange between the group's peers; therefore, it requires committed students. Ferreiro \& Espino (2012) state that groups should be made up of a maximum of four members since sometimes they will fulfill a double function. To deepen the productivity of a group work will depend on the capacity of each of the members, by sticking to cooperative work it will allow the change to take place in their different functions, this is how the student will acquire high performance. (Reyes \& Reyes, 2017). Individual responsibility and personal appreciation mean that the entire group should achieve its objectives by generating the common good, each of its members is responsible for carrying out the part of the work that corresponds to him, in this situation, no one can stop working and much less employing the work of another colleague, its purpose is that through work in learning teams students are academically strengthened, affectively, it allows to determine who needs more help, support to carry out their task. Concerning interpersonal skills, social skills are practiced as clear, precise communication; the support that is given between them is reciprocal. They constructively solve their problems, accept themselves as they are, and trust between themselves. These skills are an essential requirement for good performance in group work.

Group processing or self-evaluation consists of identifying the behaviors that each of the students manifests during group work and is even part of the process of measuring their achievements, and from this, they propose changes, improvements to achieve the proposed objectives (Bermejo et al., 2021). Group processing allows adequate reflection and students' participation in work teams; therefore, this process is usually critical, reflective, and consistent. Individual leadership is banished, evidencing shared leadership; each of the students has protagonism, participation, and responsibility at work. In turn, cooperative learning presents the following structure: activity, reward, and authority; according to Bustamante (2017), the teacher to organize their learning sessions makes decisions regarding the actions that the students are going to carry out, about how they will motivate, who will decide or have the degree of control that students will have over their own activities. Therefore, the structure of the activity has as its main characteristic the interaction between students in small groups according to the activities they carry out, evidencing the common learning and interdependence between them. In addition, the 


\section{International Journal of Environmental, Sustainability, and Social Sciences ISSN 2720-9644 (print); ISSN 2721-0871 (online) \\ https://journalkeberlanjutan.com/index.php/ijesss}

reward structure has an important meaning because each of the students is performing efficiently to achieve personal success, and in turn, that of all the members of their group, they are interacting cooperatively to achieve the desired goal. Furthermore, the authority structure strengthens the degree of autonomy of the students; they plan, organize and decide how to do the activities in a creative, innovative way, demonstrating all their skills and knowledge, the teacher in this sense determines what they learn and how much they learn, while the students decide autonomously how to execute it or carry out their work.

Cooperative work maximizes the assimilation of knowledge in each group member by sharing their knowledge, evidence, skills, abilities, materials, establishing, assuming their agreements and common goals. At the same time, the climate in the classroom improves, the students feel motivated, committed to the achievement of their learning together. (Duran \& Monereo 2012 cited by Romero et al., 2020). For (Durán \& Vidal 2004 cited by Romero et al., 2020), cooperative work is important because students develop critical thinking, self-esteem, a high positive dependence among group members, which improves their development and academic performance. According to Bustamante (2017), he argued that when applying for cooperative work, interpersonal relationships are usually more stable, students are critical, reflective, work satisfactorily among class groups; it is a methodological strategy that develops creativity and innovation. Another important aspect that this methodology fosters is the development of their social competence; it attends positively to diversity and individual differences, it reduces bullying (Juárez et al., 2019). In turn, cooperative learning allows students to be responsible in the long term, fulfill their obligations, develop socially, promoting collaboration and collective work. (Johnson et al., 1998 cited by Romero et al., 2020). Likewise, it is important that, it is necessary to implement learning structures with a cooperative methodology at all educational levels and even the higher level, being the fundamental axis to develop skills. (Sánchez Marín et al., 2019). In turn, cooperative work is important because it allows integrating, creating, and sharing knowledge, facilitating student learning, creating in them a lasting change to apply it in different contexts (Sánchez Marín et al., 2019). The advantage of applying this strategy in the classroom is that mutual help becomes true, genuine, students show personal and social development and improve their academic and affective performance, expectations that you want to achieve such as curiosity, perseverance, success and become constant for the future. (Romero et al., 2020).

Cooperative work brings great benefits in pedagogical work, at an academic, social, and psychological level at different levels of study. Research proves that cooperative work raises high performance, eradicating competitive and individualistic work (Johnson et al., 1999); (Reynosa Navarro et al., 2020). This position is a strategy that can be developed in different contexts; they perceive learning, managing to develop social competence, and strategies can even be included in masterclasses and incorporate communication through ICT and neuroscience (Sánchez et al., 2019). Cooperation through a program has favored access to the writing system of students; therefore, it is important to encourage family participation through cooperative dynamics; it allows integrating skills that facilitate le; this in writing, this cooperative practice is a strategy of interest in improving lexical and semantic development, as well as a written language (Gutierrez-Fresnada et al., 2020). In universities, teaching-learning has been transformed by applying these spaces of interaction, cooperation that promotes a culture of research in groups to achieve the competencies and aptitudes in each of the professionals, for the achievement of a purpose, aspects in the realization must be considered Of cooperative activities such as group agreements, respect for diversity and equitable participation, teamwork competence is the most demanded, the teacher interacts as an advisor, guide, supervisor, evaluates planning, quality, distribution of the tasks, the responsibilities assigned by each member of the group (Bedregal et al., 2020). 


\section{International Journal of Environmental, Sustainability, and Social Sciences ISSN 2720-9644 (print); ISSN 2721-0871 (online) \\ https://journalkeberlanjutan.com/index.php/ijesss}

This methodology allows the teacher to use research tools, improve his practice, because he will adapt it to his reality, understanding the needs of his students, in turn, improves the climate allowing the student to explain his learning process, improves conflicts, understanding and mutual knowledge, making students develop competencies. Group work is the teacher's work of the teacher is a capacity that determines educational quality, helps in planning, execution, and consensus of the proposed objectives. As a result, students have better social competencies living in a controlled environment and close to a work field (Izquierdo et al., 2019).

\section{RESULTS AND DISCUSSION}

In the area of Physical Education in university institutions, this cooperative methodology has been applied to promote values, interaction in heterogeneous groups; it requires students to become aware to carry out content work and communication, but to internalize learning, it is It is essential to have a climate of empathy, respect, and tolerance, generating knowledge, learning for life (Bermejo et al., 2021). Cooperative learning improves the academic performance of students by making them acquire competencies; it is suitable for teaching experimental sciences since in this subject, traditional, expository classes are still taught, obtaining ineffective results; when activating this methodology, the students are reflective, critical, they are the protagonists of the construction of their learning Herrada (2018). Likewise, Cooperative work is a potential strategy that maximizes the participation of the members, achieving a positive impact on learning. Called didactics of teaching-learning in the computational field (Revelo et al., 2018). Through cooperative work, students exercise not only integrative learning but also develop social skills, and knowledge is measured through self-evaluation and co-evaluation (Garrote et al., 2019). Cooperative work is shown as a democratic strategy in student learning since it occurs in a shared way. They acquire norms, agreements, democratic values that are very important to relate to others in our society. Erbil and Kocabas (2018).

Cooperative work according to all the information and practices analyzed is a relevant strategy to apply in primary education classrooms because it is an active learning methodology, develops disproportionate interest, ensuring high performance in students, and increases benefits in each of the students in an academic, cognitive, psychological and socio-educational way. Furthermore, the application of this cooperative strategy allows students to acquire skills adjusting to the current national curriculum and current job demands such as leadership practice, assertive communication, autonomy, group work, decision-making, critical position, division of tasks, coordination when working in teams, conflict resolution, and autonomy, achieving the integral development of students.

\section{CONCLUSION}

Students are aware of their own changes when applying this dynamic, active, coordinated strategy, in which they learn to respect themselves, express and defend their own position, ideas and even feel satisfied, motivated by wanting to learn and learn, expose and share all their achievements showing development and mastery of the subject to be discussed. Through this process, students learn to value the contribution of others to achieve the success of all; they feel support throughout the activity process, demonstrating a commitment to do their job well. It is a strategy that helps the teacher improve the classroom climate in the face of conflict situations that arise personally and in the low performance of students, showing a good coexistence and avoiding the practice of disruptive behaviors.

For the achievement of cooperative work in primary education classrooms, a change is essential concerning a meaningful dynamic learning strategy that allows active, coordinated learning, establishing their own agreements, work norms, much depends on the motivating attitude of the student. As a teacher, students are infected with this optimism by assuming their 


\section{International Journal of Environmental, Sustainability, and Social Sciences ISSN 2720-9644 (print); ISSN 2721-0871 (online) \\ https://journalkeberlanjutan.com/index.php/ijesss}

challenges with effort, dedication, and even overcoming their mistakes and frustrations by applying techniques focused on emotional skills.

\section{REFERENCES}

Arias, L. (2017). El aprendizaje por proyectos: una experiencia pedagógica para la construcción de espacios de aprendizaje dentro y fuera del aula. Ensayos Pedagógicos, 12(1), 51-68. https://dialnet.unirioja.es/descarga/articulo/6095686.pdf

Bedregal-Alpaca, N., Padron-Alvarez A., Tupacyupanqui-Jaén, D., Cornejo-Aparicio, V. (2020) Aprendizaje basado en investigación y trabajo cooperativo en ingeniería civil: propuesta desde la integración de las TIC. In M. Sosa (General Conference Chair). 18th LACCEI International Multi-Conference for Engineering, Education, and Technology: “Engineering, Integration, and Alliances for a Sustainable Development" "Hemispheric Cooperation for Competitiveness and Prosperity on a Knowledge-Based Economy". LACCEI - Latin American and Caribbean Consortium of Engineering Institutions, Colombia. http://dx.doi.org/10.18687/LACCEI2020.1.1.44

Bermejo, J. M., Pulido, D., Galmés, A. M., Serra, P., Vidal, J., \& Ponseti, F. J. (2020). Physical Education and university: Evaluation of a teaching experience through cooperative learning. Retos, 2041(39), 90-97. https:/ / doi.org/10.47197/retos.v0i39.77834

Bustamante, J. (2017). El aprendizaje cooperativo: Una competencia imprescindible en educación $\begin{array}{llll}\text { superior. } & \text { Educación } & \text { Superior, } & 26-35 \text {. }\end{array}$ http://www.scielo.org.bo/pdf/escepies/v2n1/v2n1_a03.pdf

Díaz, F., \& Hernández, G. (1999). Estrategias docentes para un aprendizaje significativo. McGrawHill.

Duran, D. \& Monereo, C. (2012). Entramado: Métodos de aprendizaje cooperativo y colaborativo. Horsori.

Duran, D., \& Vidal, V. (2004). Tutoría entre iguales: de la teoría a la práctica. Editorial Graó.

Erbil, D. G., \& Kocabaş, A. (2018). Cooperative Learning as a Democratic Learning Method. Journal of Research in Childhood Education, 32(1), 81-93. https://doi.org/10.1080/02568543.2017.1385548

Estrada, M., Monteferrer, D., y Moliner M., A., (2016). Cooperative Learning and Socio-Emotional Skills: A Teaching Experience in Sales Techniques Course. Formación Universitaria, 9(6), 4362. https://doi.org/10.4067/S0718-50062016000600005

Ferreiro, R. y Espino, M. (2012). El ABC del aprendizaje cooperativo: Trabajo en equipo para aprender y enseñar. Editorial Trillas.

Garrote, D., Jiménez-Fernández, S., Martínez-Heredia. N. (2019). Cooperative Work as a Training Tool for University Students. REICE. Revista Iberoamericana sobre Calidad, Eficacia y Cambio en Educación, 17(3), 41-58. https:/ / doi.org/10.15366/reice2019.17.3.003

Gutiérrez-Fresneda, R., Jiménez-Pérez, E., \& De-Vicente-Yagüe-Jara, I. M. (2020). Effect of Cooperative Work on Learning to Write through Family Involvement. Estudios sobre Educación, 39, 229-246. https:// doi.org/10.15581/004.39.229-246

Herrada, R. \& Baños, R. (2018). A review of cooperative learning experiences in experimental sciences. Revista de Educación: Campo Abierto, 36 (2), 157-170. http://dehesa.unex.es/bitstream/10662/8462/1/0213-9529_37_2_157.pdf

Izquierdo, T., Asencio, E., Escarbajal, A., y Rogriguez, J. (2019). Cooperative learning in teaching of teachers of Primary Education. Revista de Investigación Educativa, 37(2), 543-559. https://doi.org/10.6018/rie.37.2.369731

Johnson, D. W., Johnson, R. T., y Holubec, E. J. (1994). Los nuevos círculos de aprendizaje: La cooperación en el aula y la escuela. Aique, S.A.

Johnson, D., Johnson, R. T., \& Smith, K. (1991). Active learning: Cooperation in the college classroom. Interaction Book Company. 


\section{International Journal of Environmental, Sustainability, and Social Sciences ISSN 2720-9644 (print); ISSN 2721-0871 (online) \\ https://journalkeberlanjutan.com/index.php/ijesss}

Johnson, D., Johnson, R. y Smith, K. (1998). Active learning: Cooperation in the college classroom. The Annual Report of Educational Psychology in Japan (47 ).https://www.researchgate.net/publication/234568124_Active_Learning_Cooperation_in_t he_College_Classroom/citation/download

Juárez., M., Rasskin I., y Mendo., S. (2019). Cooperative Learning, an active methodology in the 21st Century: a review. Revista Prisma Social, 26(1), 200-210. https://revistaprismasocial.es/article/view/2693/3321

Molina, T. (2020). Cooperative Work as an instrument to build heritage education. Revista de la Facultad de Educación de Albacete, 35(1). 51-http:/ / orcid.org/0000-0001-7157-0324

Revelo, O., Collazos, C., y Jiménez, J. (2018). Collaborative work as a didactic strategy for teaching/learning programming: a systematic literature review. TecnoLógicas, 21(41). 115134. http://www.scielo.org.co/pdf/teclo/v21n41/v21n41a08.pdf

Reyes, M., y Reyes A. (2017). Aprendizaje cooperativo: estrategia didáctica y su impacto en el aula. Congreso Nacional de Investigación Educativa. COME.

Reynosa Navarro, E., Urbina Ganvini, E. L., De la Torre Zavala, S. D., Becerra Niño, L. M., orbegoso Dávila, A. M., Saldaña Bernal, C. K., Montoya Ulloa, E. A., \& Cruz Rosa, J. (2020). Integral characteristics of the entrepreneurial leader: a pedagogical experience. Journal of Entrepreneurship Education, 23(5), 1-11. https://www.abacademies.org/articles/integralcharacteristics-of-the-entrepreneurial-leader-a-pedagogical-experience-9470.html

Romero, E., Mora, A., González W., Garbanzo, P., Zamora, J., Quirós F., y García, S., (2020). Development of motivation in secondary students through the implementation of an educational program in Plastic Arts based on Cooperative Learning. Cuadernos De Investigación Educativa, 11(2), 117 - 131. https:/ / doi.org/10.18861/cied.2020.11.2.2990

Sanchez Marin, F. J., Concepcion Parra-Merono, M., \& Pena-Acuna, B. (2019). Experiences of Cooperative Work in Higher Education. Perceptions About Its Contribution To the Development of Social Competence. Vivat Academia, (147), 87-107. https://go.gale.com/ps/anonymous?id=GALE\%7CA593802196\&sid=googleScholar\&v=2.1 \&it=r\&linkaccess $=a b s \& i s s n=15752844 \& p=I F M E \& s w=w$

Sánchez-Marín, F. J., Parra-Meroño, M. C., \& Peña-Acuña, B. (2019). Experiences of cooperative work in Higher Education. Perceptions about its contribution to the development of social competence. Vivat Academia, (147), 87-108. https://doi.org/10.15178/va.2019.147.87-108

Vázquez Antonio, J. M. V., Mosqueda, J. S. H., Vázquez-Antonio, J., Hernández, L. G. J. y Calderón, C. E. G. (2017). Collaborative work and socioformation: a path to complex $\begin{array}{llll}\text { knowledge. } \quad \text { Educación } & \text { y }\end{array}$ https://doi.org/10.17081/eduhum.19.33.2648

Vélez, A. P. y Olivencia, J. J. (2019). Cooperative and collaborative methodologies in teacher training for interculturality. Tendencias Pedagógicas, 33, 37-46. https://doi.org/10.15366/tp2019.33.003 